\title{
Student learning strategies higher level
}

\section{Estrategias de aprendizaje en estudiantes de nivel medio superior}

\author{
SESENTO, Leticia*†' \& LUCIO, Rodolfo" \\ Colegio Primitivo y Nacional de San Nicolás de Hidalgo, Mexico. \\ "Universidad Michoacana de San Nicolás de Hidalgo, Faculty of Veterinary Medicine and Zootechnics, Mexico. \\ ID $1^{\text {st }}$ Autor: Leticia, Sesento / ORC ID: 0000-0002-6456-058X, Researcher ID Thomson: S-6997-2018, CVU CONACYT \\ ID: 449302
}

ID $1^{\text {st }}$ Coauthor: Rodolfo, Lucio / ORC ID: 0000-0002-0535-3652, Researcher ID Thomson: X-2391-2018, CVU CONACYT ID: 947303

DOI: $10.35429 / J S E M .2020 .21 .7 .1 .7$

Received July 13, 2020; Accepted December 28, 2020

\begin{abstract}
The objective of this work is to know the type of learning strategies used by the students of the Primitive and National School of San Nicolás de Hidalgo. The teachers of upper middle level mostly consider that the students learned to use these strategies the previous years, from their training. For this reason, regardless of the grade level that the teacher teaches, the teacher must make a diagnosis of what strategies they can handle that develops their learning, or teach these strategies to their students so that they can assimilate the content autonomously. It is a crosssectional, descriptive and correlational investigation. A sample was managed, made up of 378 students enrolled in the second and fourth semester of upper secondary education in the February / August 2020 school year. The research was achieved through the Assessment Questionnaire of Learning Strategies for University Students (CEVEAUPEU), instituted by Gargallo, SuárezRodríguez and Pérez-Pérez (2009). 1.9\% have regular study strategies, $75.4 \%$ have good study strategies and finally $21.7 \%$ have excellent strategies. The results allow to conclude that the participants demand greater knowledge and use of the strategies of processing and use of the information EEP (grouped) related to the search, selection, processing and use of the information, so essential in this time when it exceeds the information, as a result of technological and scientific advances.
\end{abstract}

\section{Resumen}

El objetivo del presente trabajo es conocer el tipo de estrategias de aprendizaje que utilizan los estudiantes del Colegio Primitivo y Nacional de San Nicolás de Hidalgo. Los docentes de nivel medio superior en su mayoría consideran que los estudiantes aprendieron a usar estas estrategias los años anteriores, de su formación. Por ello manera independiente del grado escolar que enseñe, el profesor corresponde hacer un diagnóstico sobre que estrategias saben manejar que desarrolla su aprendizaje, o bien enseñar estas estrategias a sus estudiantes para que asimilen de forma autónoma los contenidos. Es una investigación transversal, descriptivo y correlacional. Se manejó una muestra, conformada por 378 estudiantes inscritos en segundo y cuarto semestre de educación media superior en el ciclo escolar febrero/agosto 2020. La investigación fue lograda a través del Cuestionario de Evaluación de las Estrategias de Aprendizaje para Estudiantes Universitarios (CEVEAUPEU), instituido por Gargallo, Suárez-Rodríguez y Pérez-Pérez (2009). Los resultados obtenidos son los siguientes: el $1.9 \%$ tiene estrategias regulares de estudio, el $75.4 \%$ cuenta con buenas estrategias de estudio y finalmente el $21.7 \%$ tiene excelentes estrategias. Los resultados admiten concluir que los participantes demandan mayor conocimiento y utilización de las estrategias de procesamiento y uso de la información EEP (agrupado) relacionadas con la búsqueda, selección, procesamiento y uso de la información, tan indispensables en esta época en la que excede la información, como resultado de los adelantos tecnológicos y científicos.

Estrategias, Estudiantes, Nivel medio superior

Citation: SESENTO, Leticia \& LUCIO, Rodolfo. Student learning strategies higher level. Journal of Systems and Educational Management. 2020. 7-21:1-7.

\footnotetext{
*Correspondence to Author (Email: leticiasesentogarcia@yahoo.com.mx)
}

$\dagger$ Researcher contributing as first Author. 


\section{Introduction}

Learning strategies are actions or mental methods that students intentionally develop during their educational process in order to facilitate better academic performance (Beltrán. 1993; Monereo. 1994; Pérez. 2010). They differ from learning methods and techniques (Beltrán, 2003). The techniques have to do with the implementation of mental operations in relation to matters of learning (for example: attention, understanding, and acquisition), techniques are operational actions. Among the processes and techniques are strategies, which are not as perceptible as techniques, nor as hidden (for example: organizing information to perceive meaning).

They are guidelines that allow considering appropriate decisions in correspondence with an explicit matter, at the relevant time. The use of learning strategies involves the student having an action plan. When the student knows what to do to learn, he does it, and controls it, to continue learning autonomously. Learning strategies comprise a set of cognitive resources and procedures used by students during learning and are directly dependent on other dispositional and motivational factors that involve planning, control and supervision actions, help to recognize significant learning and satisfactory academic effects (Ben Eliyahu and LinnenbrinkGarcía, 2015; Delgado, Inglés, GarcíaFernández, Castejón, and Valle, 2010; Ellis, Denton, and Bond, 2014; Gaeta, Teruel, and Orejudo, 2012; Gargallo, Campos, and Almerich, 2016; Karabenick and Zusho, 2015; Miñano Pérez, Castejón Costa, and Gilar Gorbí, 2012).

From the perspective of Beltrán (1998), learning demands the readjustment and organization of several factors such as stimulation, beliefs, previous discernment, interactions, new information, skills and strategies. In such a way that students must specify plans, recognize progress, manage skills and strategies, as well as other mental resources in order to achieve their goals. Learning strategies not only form the ability to learn and relearn problems, but this in itself includes the intellectual development of the student, the potentialization of their skills, understanding these as flexible and suitable organizations to be reformed and developed.

\section{Development}

From a few years on, a huge effort has been embedded in educational environments, multiple studies concur on topics on learning strategies. Expressions such as "teaching to think", "learning to learn", "learning to think", etc., place us in front of one of the fundamental lines of research within school learning in recent years and, also, are linked to the most important slope. clearly analogous to cognitive practice in the study of the matter of learning. We will start by defining what a learning strategy is; tactics and skills that translate into a significant difference: the initial two involve conscious and goaloriented actions and the current one, on the other hand, only involves work; In other words, strategies and tactics circumscribe motivations, methods and decisions that end up requiring skills (Genovard, 1990, p. 10).

We could say that strategies are tactics that symbolize the effort that the student has to make to solve, conceive and adopt the information that accumulates in the teachinglearning process (Tay, 2013). They are the works that check to provide meaning to the information. There are other systematizations of learning strategies (Hartley, 1998; O'Malley and Chamot, 1990; Oxford, 1990; Riding and Rayner, 1998; Weinstein and Mayer. 1985). The generality of the systematizations includes the works that are owned with cognitive skills and those that are owned with those of the cordial type (Gagne and Driscoll, 1988). This work is based on the codification of Gargallo, SuárezRodríguez and Pérez-Pérez (2009), who take into account three dimensions consistent with learning: will, capacity and autonomy (want, power and decide).

The classification of Gargallo, SuárezRodríguez and Pérez-Pérez (2009) is based on the conceptions of Pintrich and Gooth (1990); Pintrich, Smith, García and Mckeachie (1991); Pozo and Monereo (1999); and Roces, Tourón and González (1995). The classification unites two types of strategies: (1) those that set the learning process on track and help conserve effort (motivational, friendly, metacognitive, context recognition and interaction and resource management); and (2) strategies related to the information process, a necessary aspect in today's society (research, choice, process and application of information). 
The study of learning strategies acquires special note from the Comprehensive Reform of Higher Secondary Education (RIEMS) implemented in 2011. The RIEMS indicates that students are responsible for being competent for autonomous learning. This learning requires that they know and manage other skills to, for example, motivate themselves, plan, make decisions, organize information and inspect the study context (Ministry of Public Education, 2011).

\section{Theoretical framework}

Most high school teachers consider that students learned to use these strategies in the previous years of their training. For this reason, regardless of the school grade that they teach, the teacher corresponds to make a diagnosis about which strategies they know how to handle that develops their learning, or to teach these strategies to their students so that they autonomously assimilate the contents. It is important that the strategies are taught in a similar way as the curricular contents of each subject, or, in class meetings essentially chosen for it. Before that, the educator belongs to know the theories that have been expressed in the area of psychology to show how students self-regulate their learning. Next we will review the concept of self-regulated learning and academic achievement

\section{Self-regulated learning and academic achievement}

The independent, self-regulated or autonomous learning of students in the classroom is guided by the theories of Pintrich (2000), Zimmerman (2000) and Winne (2001), Pintrich (2000) provides a theoretical framework that comprises four phases and four areas to expose how students systematize their learning. The four phases are planning, monitoring, control, and reflection. In the first phase, the student plans, establishes goals or objectives, and activates her knowledge of the context, the text and about herself. In phase two, the student shows that they have metacognitive awareness and monitor their cognition or learning. In stage three, she chooses the cognitive strategy and encouramatizes other aspects of the context, the task, and herself. Finally, he makes judgments and reconsiders about the context, the task and himself. In phases they live four spaces in which self-regulation succeeds: cognition, motivation or affect, behavior and context.
These phases are not hierarchical, they manage to happen in a similar and dynamic way.

Likewise, Zimmerman (2000) proposes a model to expose how learning is self-regulated. In this model, self-regulation has three phases: anticipation, performance, control, and selfreflection. In the anticipation phase the student prepares the atmosphere for what he is going to learn. The more self-regulated or autonomous have objective perspectives, set goals with determined effects, and identify the best procedure to maximize the means of success in an individual learning task. In the second phase, which occurs during the learning process, the student uses specific strategies, such as asking himself: What can I do to avoid being distracted? In the last phase, when they complete the learning task, the autonomous or self-regulated students reconsider to self-assess.

For Winne (2001) there is a third perspective that is based on information processing theory. Her model contains four phases: understanding the task, setting goals and planning how to achieve them, putting strategies into practice, and cognitively adapting to study. In the first phase, the student forms a perception of the task from the information they get from the context, their practice and their previous knowledge. In the second phase, develop goals and plans. In the third phase, choose and manage strategies. In the fourth phase, monitor and assess the discrepancies between what was set as a goal and what it achieved. This model allows the phases to be carried out periodically, while the student monitors, notices differences and adjusts her plan or her strategies for selfregulation of her learning.

Stimulating students to be autonomous in their learning, aims to perceive how learning is self-regulated. The theories of Pintrich (2000), Zimmerman (2000) and Winne (2001) are the starting point. In this way, it is required to know which are the strategies that students already use and which are not. This is achieved through a tool for evaluating the use of strategies. In addition, it is essential to know if the low academic performance of some students corresponds to the lack of use of appropriate strategies or is due to other components. 
Academic performance is the level of effectiveness in achieving the curricular objectives for the different subjects and is formulated through a grade or average, some call it school performance (Navarro, 2003).

Numerous studies have argued that learning strategies are directly concerned with the quality of learning and allow identifying the origins of the level of performance of students (Beltrán, 2003; Martín, García, Torbay and Rodríguez, 2008). It happens that two students with the same intellectual potential, the same motivation and recipients of the same type of instruction that have a different performance because they handle learning strategies.

The objective of the study shown here was to study the learning strategies used by high school students from a private school in northeastern Mexico in their physics classes. In addition, the relationship between the learning strategies that the students reported using and their academic performance was investigated, represented by the grades they said they had obtained in the semester prior to the study. The research questions that guided the work are: What are the learning strategies used by students in the physics subject? What is the relationship between learning strategies used by students in Physics subjects and their academic performance in that subject?

For Saldaña (2014) the acquisition of skills and competences help the strategic use of knowledge as a fundamental part of professional training; Therefore, it is the role of every teacher to clarify learning strategies in their students and, in this way, originate self-regulated learning. Also, it is observed that critical thinking and metacognitive self-regulation are high-level learning strategies; consequently, they go in correspondence to the characteristics with all the motivational devices, showing the strongest relationship with internal motivation and the least energetic with recognition of control. the strategies improve self-direction of learning but must be appropriate for the student. Strategy such as learning, recording ideas, studying, accentuating data and investigating the meaning of words, among others; will transport to optimize the entrepreneurial attitude of the students.
Strategies enhance self-direction of learning but must be appropriate for the student. Strategy such as studying, writing down ideas, reading, underlining data and looking for the meaning of words, among others; They will lead to improving the entrepreneurial attitude of students. Next, we will analyze the learning strategies used by students of the Colegio Primitivo y Nacional de San Nicolás de Hidalgo (CPNSNH), belonging to the Universidad Michoacana de San Nicolás (UMSNH). Located in an urban area of Morelia. The second and fourth semester students this study was carried out during the time of social isolation in May 2020.

\section{Method}

It is a cross-sectional, descriptive, and correlational investigation. It is transversal because the information was collected in a single time. It is descriptive because it calculates the action of two variables and its intention is to know how these variables are manipulated in a given place or situation. It is correlational because it studies the type of correspondence that exists between learning and academic performance.

\section{The sample}

A sample was managed, made up of 378 students enrolled in the second and fourth semesters of upper secondary education in the February / August 2020 school year. The universe is made up of 535 students, with a bias in the sample of $29.3 \%$. It was a non-probabilistic sample. Sampling by intentional selection consists of the choice, by non-random methods, of subjects who are in a certain place, at a certain moment and decide or not to collaborate. The sample, therefore, is not representative and the results cannot be generalized to subjects from other educational contexts. The subjects were between 15 and 18 years old. $72.8 \%$ women and $27.2 \%$ are men.

\section{The data collection instrument}

The research was achieved through the Assessment Questionnaire of Learning Strategies for University Students (CEVEAUPEU), instituted by Gargallo, SuárezRodríguez and Pérez-Pérez (2009). 
It consists of 88 items organized in two scales: (1) Affective, support and control strategies; and (2) Strategies related to information processing. The scales are subdivided into six subscales and 25 strategies.

The responses to the questionnaire were evident by the subjects on a Likert-type scale, where 1 indicated Strongly Disagree, 2 Disagree, 3 Undecided, 4 Agree and 5 Strongly Agree. The questionnaire was answered by the subjects in a Google drive form. The questionnaire was answered by the subjects in a group, at home. The objective of the investigation was explained to them and they were given free time to respond. On average, it took them 15 minutes to fill out the questionnaire.

\section{Data analysis}

The universe of the population is made up of 378 students, of which $72.8 \%$ women and the remaining population women.

The parents of the students $1.6 \%$ have no studies, $7.4 \%$ have Primary, while $26.2 \%$ Secondary, Baccalaureate $31.2 \%$, Bachelor $25.1 \%$, Master $6.1 \%$ and Doctorate $1.6 \%$.

For mothers, the level of education is as follows: Without studies $1.1 \%$, Primary $8.7 \%$, Secondary $26.7 \%$, Baccalaureate 27.0, Bachelor $29.1 \%$, Master $6.7 \%$. students:

In relation to the achievement of

54.5 did not fail any subject in extraordinary while 17.7 , while $9.5 \%$ failed 1 subject, failed 2 subjects, $6.3 \%$ failed three subjects and $6.3 \%$ and accredited 4 subjects and $1.9 \% 5$ subjects.

The percentage of courses accredited by students is $69.8 \%$ no subject, while $17.7 \%$ must 1 subject, $7.4 \% 2$ subjects, while $1.6 \%$ must 3 subjects.

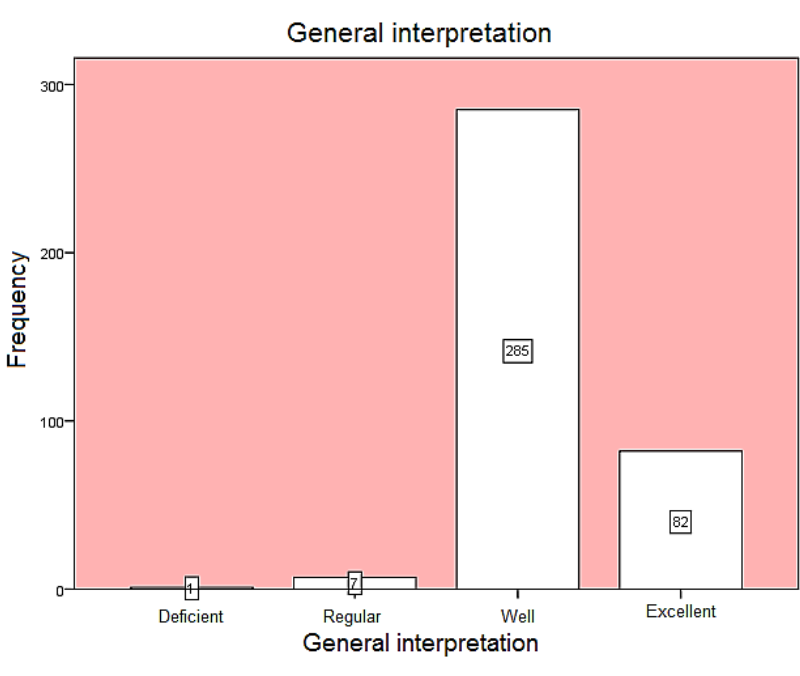

Graphic 1

$1.9 \%$ have regular study strategies, $75.4 \%$ have good study strategies and finally $21.7 \%$ have excellent study strategies.

\section{Conclusion}

The CEVEAPEU questionnaire used contains 88 items initially validated in Spanish university students. This research indicated that when used with Mexican students of the upper secondary level in the Colegio Primitivo y Nacional de San Nicolás de Hidalgo, only $46.59 \%$ of the items resulted with adequate reliability (a> 0.7). Therefore, it is believed that, for these specific students, it is preferable to monopolize an adapted version of the instrument.

Motivational strategies SEM (grouped) 4.26, Affective components RCT (grouped) 3.89, Metacognitive strategies ESM (grouped) 4.20, Strategies for context control, social interaction and resource management ECO (grouped) 4.10, Strategies of search and selection and information EEB (grouped) 4.05, Strategies for processing and use of EEP information (grouped) 3.66.

The results allow to conclude that the participants demand greater knowledge and use of the strategies of processing and use of the information EEP (grouped) related to the search, selection, processing and use of information, so essential in this era in which it exceeds the information, as a result of technological and scientific advances. To constitute citizens who develop a society founded on knowledge essentially involves guiding them in the efficient use of available scientific information. For this, the use of appropriate strategies is essential. 


\section{References}

Beltrán, Jesús. (1993). Procesos, estrategias y técnicas de aprendizaje. Madrid: Síntesis Beltrán, Jesús. (2003). Estrategias de aprendizaje. Revista de Educación,332. 5573.

Casal, Jordi y Mateu, Enric, (2003). Tipos de muestreo. Rev. Epidem. Prev. Med.,1(1). 37.

Gagne, Robert Mills y Driscoll, Marcy P. (1988). Essentials of learning for instruction. NJ: Prentice Hall.

Gargallo, Bernardo, Suárez-Rodríguez, Jesús, M., y Pérez-Pérez, Cruz. (2009). El cuestionario CEVEAPEU. Un instrumento para la evaluación de las estrategias de aprendizaje de los estudiantes universitarios. Revista Electrónica de Investigación y Evaluación Educativa,15(2). 1-31.

Hartley, James. (1998). Learning and studying: A research perspective psychology focus. Taylor \& Francis. Londres: Routledge Martín, Eduardo, García, Luis A., Torbay, Ángela y Rodríguez, Teresa. (2008). Estrategias de aprendizaje y rendimiento académico en estudiantes universitarios. International Journal of Psychology and Psychological Therapy, 8(3). 401-412

Monereo, Carles. (1994). Estrategias de enseñanza aprendizaje. Formación del profesorado y aplicación en la escuela. Barcelona: Graó

Navarro, Rubén Edel. (2003). El rendimiento académico: concepto, investigación y desarrollo. Revista Electrónica sobre Calidad, Eficacia y Cambio en Educación, 1(2).12-19.

O'Malley, J. Michael y Chamot, Anna Uhl. (1990). Learning strategies in second language acquisition. Cambridge: Cambridge University Press.

Oxford, Rebeca. (1990). Language learning strategies. Boston, Mass: Heinle and Heinle Publishers.
Pérez Acosta, Ricarte Xavier. (2010). Estrategias cognitivas empleadas por alumnos con bajo rendimiento en álgebra para resolver una prueba. (Tesis inédita de Maestría). México. Universidad Autónoma de Yucatán. Recuperado el 18 de agosto del 2011, de http://posgradofeuady.org.mx/wpcontent/uploads/2011/01/Perez-RicarteMIE2010.pdf.

Pintrich, Paul R. (2000). The role of goal orientation in self-regulated learning. En Monique Boekaerts, Paul R. Pintrich, y Moshe Zeidner (eds.), Handbook of selfregulation (pp.452-502). San Diego, CA: Academic Press.

Riding, Richard y Rayner, Stephen. (1998). Cognitive styles and learning strategies: Understanding style differences in learning and behavior. London: David Fulton Publishers.

Secretaría de Educación Pública. (2011). Reforma Integral de la Educación Media Superior en México. México: SEP.

Saldaña, L. (2014). Estrategias de aprendizaje, motivación y rendimiento académico en alumnos de nivel medio superior. [Tesis de maestría]. México: Universidad Autónoma de Nueva León.

Tay, Bayram. (2013). Elaboration and organization strategies used by prospective classteachers while studying social studies education textbooks. Eurasian Journal ofEducational Research, 13(51), 229-252. Recuperado de http://www.ejer.com.tr/?git=22 $\&$ kategori $=99 \&$ makale $=863$.

Weinstein, Claire Ellen y Mayer, Richard E. (1985). The teaching of learning strategies. En Merlin C, Wittrock, (ed.), Handbook of research on teaching (pp. 315-327). NY: MacMillan.

Winne, Phillip H. (2001). Self-regulated learning viewed from models of information processing. En Barry J. Zimmerman y Dale H. Schunk (eds.), Self-regulated learning and academic achievement: Theoretical perspectives (pp. 153-189). NJ: Erlbaum Mahwah. 
Zimmerman, Barry J. (2000). Attaining selfregulation: A social cognitive perspective. En Monique Boekaerts, Paul R. Pintrich, y Moshe Zeidner (eds.), Handbook of self-regulation (pp. 13-39). San Diego, CA: Academic Press.

Ben-Eliyahu, A., y Linnenbrink-Garcia, L. (2015). Integrating the regulation of affect, behavior, and cognition into selfregulated learning paradigms among secondary and postsecondary students. Metacognition Learning, 10, 15-42. doi: 10.1007/s11409-014-9129-8

Delgado, B., Inglés, C. J. García-Fernández, J. M., Castejón, J. L., y Valle, A. (2010). educativo: las cooperativas de trabajo asociado. Percepciones de sus directivas. Enseñanza, 20, 51-84.

Ellis, A. K., Denton, D. W., y Bond, J. B. (2014). An analysis of research on metacognitive teaching strategies. Procedia-Social and Behavioral Sciences, 116, 4015 4024. doi: 10.1016/j.sbspro.2014.01.883.

Gargallo, B., Campos, C., y Almerich, G. (2016). Aprender a aprender en la universidad. Efectos sobre las estrategias de aprendizaje y el rendimiento académico. Cultura y Educación, 9, 1-40. doi: 10.1080/11356405.2016.1230293.

Miñano, P., y Castejón, J. L. (2008). Capacidad predictiva de las variables cognitivomotivacionales sobre el rendimiento académico. Revista Electrónica de Motivación y Emoción, 28(11).

Genovard, C. (1990). Las estrategias de aprendizaje desde la perspectiva de la Psicología de la Instrucción. En C. Monereo (Comp.). Enseñar a aprender ya pensar en la escuela. Ponencias. de las IJornadas de estudio sobre estrategias de aprendizaje. Madrid: Infancia y Aprendizaje.

Gómez. (28 de Septiembre de 2017). ¿Cómo funciona el proceso de enseñanza-aprendizaje? Obtenido de http://elearningmasters.galileo.edu/2017/09/28/ proceso-de-ensenanza-aprendizaje.
Monereo, Carles (coord.), Montserrat Castelló, Mercè Clariana, Montserrat Palma, Maria L. Estrategias de enseñanza y aprendizaje Formación del profesorado y aplicación en la escuela. Pérez. Editorial Graó. Barcelona. Primera edición: 1994. Segunda edición: 1995. Tercera edición: febrero 1997. Cuarta edición: octubre 1997. Quinta edición: 1998. Sexta edición: 1999. 